\title{
Radiological Evaluation of Olfactory Fossa with Cone-Beam Computed Tomography
}

\author{
Ceren Özeren Keşkek¹, Emre Aytuğar² \\ ${ }^{1}$ Izmir Training Dental Hospital, Izmir, Turkey. \\ ${ }^{2}$ Department of Oral and Maxillofacial Radiology, Faculty of Dentistry, Izmir Katip Celebi University, Izmir, Turkey.
}

\author{
Corresponding Author: \\ Ceren Özeren Keşkek \\ Izmir Training Dental Hospital \\ Fevzipasa Boulevard, Akinci district, No.172/2, Konak, Izmir \\ Turkey \\ Phone: +902324418181 \\ Fax: +902324893548 \\ E-mail: cerenozeren35@gmail.com
}

\begin{abstract}
Objectives: The aim of this retrospective study was to evaluate the morphology of the olfactory fossa in the Turkish population using cone-beam computed tomography according to Keros classification and to investigate the effect of age, gender and nasal septum deviation on the olfactory fossa.

Material and Methods: Olfactory fossa (OF) were analysed in coronal sections on cone-beam computed tomography images of 385 individuals. Nasal floor (NF), medial ethmoid roof point (MERP), cribriform plate (CP) heights, CP depth and width, OF width, lateral lamella-cribriform plate angle (LLCPA), and nasal septum deviation angle (NSDA) were measured. Keros and Gera classifications were made according to the measurements.

Results: According to the Keros classification, 137 of 770 OFs were type I (17.8\%), 554 (71.9\%) were type II, and 79 (10.3\%) were type III. The most common combination was Keros type II and Gera type II (45.6\%). There was a positive correlation between CP depth and LLCP angle, NF, MERP and CP heights $(\mathrm{P} \leq 0.05)$. NF, MERP, and CP heights, CP depth and LLCP angle were statistically significant differences according to Keros classification $(\mathrm{P} \leq 0.05)$. Only the right LLCP angle showed a statistically significant difference according to the NSD sides $(\mathrm{P}=0.014)$.

Conclusions: The study shows that the lateral lamella-cribriform plate angle increases as the cribriform plate depth increases. This result suggests that it may moderate the risk during endoscopic sinus surgery. Also, according to the nasal septum deviation sides, the dimensions of the olfactory fossa did not change significantly, except for the lateral lamella-cribriform plate angle.
\end{abstract}

Keywords: anatomy; cone-beam computed tomography; cribriform plate; ethmoid bone.

\author{
Accepted for publication: 29 September 2021 \\ To cite this article: \\ Özeren Keşkek C, Aytuğar E. \\ Radiological Evaluation of Olfactory Fossa with Cone-Beam Computed Tomography \\ J Oral Maxillofac Res 2021;12(3):e3 \\ URL: http://www.ejomr.org/JOMR/archives/2021/3/e3/v12n3e3.pdf \\ doi: $10.5037 /$ jomr.2021.12303
}




\section{INTRODUCTION}

The olfactory fossa (OF) is located in the anterior cranial fossa and contains the olfactory nerve. Fovea ethmoidalis (FE), which is an important component of $\mathrm{OF}$, is part of the frontal bone. FE contributes to the formation of the roof of the ethmoid bone labyrinth and separates the ethmoidal air cells from the anterior cranial fossa. There is a lateral lamella of the cribriform plate (LLCP) to which it is articulated medially. LLCP is the area most susceptible to iatrogenic damage during endoscopic sinus surgery (ESS) because of its very thin bone structure [1, $\underline{2}$.

ESS is a treatment method used in the treatment of chronic rhinosinusitis. It is also a procedure performed in nasal polyposis, mucocele, sellar and parasellar tumours, optic nerve decompression and other intracranial lesions. ESS is frequently performed, but minor and major complications may occur. Minor complications occur in 1.1 to $20.8 \%$ of procedure, and major complications occur in 0 to $1.5 \%$ [3] . Minor complications include bleeding, ostial stenosis, infection, insensitivity of the teeth or lips, and recurrence. Major complications are cerebrospinal fluid leak, eye damage, meningitis, and intracranial injuries. To reduce the risk and prevent complications, the anatomical formations in the skull base and the variations that may be encountered should be well researched and recognized [4].

Keros classification is of clinical importance for ESS and is frequently used. In this classification, the vertical distance between the cribriform plate (CP) and the ethmoid roof is measured and divided into three types according to the size of this distance. Type I $(1$ to $3 \mathrm{~mm})$ is considered the safest type because it has less depth. Type II (4 to $7 \mathrm{~mm}$ ) has acceptable reliability. Type III ( 8 to $16 \mathrm{~mm})$ is considered dangerous since the distance between the ethmoid roof and the CP level is considerably greater. As the depth of CP increases, the risk of complications during ESS increases [무의. However, Keros classification remains limited in defining the risk of penetration due to the curved shape of the skull. It is recommended to evaluate the Gera classification as well as the Keros classification. In the Gera classification; the angle between the horizontal plane continuing from the $\mathrm{CP}$ and lateral lamella (LL) and is evaluated and divided into three types: type I $\left(>80^{\circ}\right.$, low risk), type II ( $45^{\circ}$ to $80^{\circ}$, moderate risk), and type III $\left(<45^{\circ}\right.$, high risk $)$ [7] .

In patients undergoing surgery, evaluation of both classifications with appropriate imaging methods of the region is beneficial to reduce the risk. Computed tomography (CT), which provides detailed information about the paranasal sinus anatomy, is accepted as the standard imaging method before ESS []]. However, diagnostic imaging of this region and adjacent areas can be realized with cone-beam computed tomography (CBCT), which is frequently used in dentistry. Compared to CT, CBCT has advantages such as, lower radiation, lower exposure time, fewer metal artifacts, and lower priced equipment. However, the lower soft-tissue resolution is achieved with CBCT [9].

The objectives of this retrospective study were to investigate the morphology and size of olfactory fossa in coronal sections using cone-beam computed tomography, to examine the differences according to age and gender, and also to evaluate the relationship of nasal septum deviation and degree with this region.

\section{MATERIAL AND METHODS Ethical approval}

Ethical approval was obtained from Izmir Katip Celebi University, Non-lnterventional Clinical Studies Ethical Committee (02.07.2020, IRB:832). All procedures followed were in accordance with the ethical standards of the responsible committee on human experimentation (institutional and national) and with the Helsinki Declaration of 1975, as revised in 2008. Informed consent was obtained from all patients for being included in the study.

\section{Subjects}

In this study, images of 385 patients, whose CBCT records were for various reasons obtained between January 2015 and February 2020, in the Department of Oral and Maxillofacial Radiology, Faculty of Dentistry, Izmir Katip Celebi University (Izmir, Turkey), were analysed retrospectively. Exclusion criteria were the presence of craniofacial deformity or syndrome, nasal masses causing bone erosion, history of trauma, lip-palate cleft, nasal surgery history, artefacts that may prevent interpretation of image.

\section{CBCT imaging}

All of the CBCT images used were obtained using CBCT (NewTom 5G; Quantitative Radiology, Verona, Italy) device operating at $110 \mathrm{kVp}$. CBCT images taken in $15 \times 12 \mathrm{~cm}$ field of view range and $0.2 \mathrm{~mm}$ voxel size were used. Digital images were analysed using NNT (NNT Software Version 8.0; NewTom; Italy) computer software. 


\section{Assessment of CBCT images}

Measurements were made in sections with infraorbital nerves visible on both sides and are described below:

1. Nasal floor (NF) height, medial ethmoid reference point (MERP) height, CP height: The distance between the MERP (the point where the ethmoid roof joins medially to the LLCP) and the NF was measured. A horizontal plane was created passing through the infraorbital nerves on both sides. The vertical distance between this horizontal plane and MERP was defined as MERP height. The vertical distance between $\mathrm{CP}$ and this horizontal plane was defined as the height of CP. Measurements were carried out bilaterally and between the sides were compared (Figure 1).

2. CP depth and Keros classification: CP depth was determined by measuring the distance between MERP and CP. It was classified into 3 types according to Keros classification: type I (1 to $3 \mathrm{~mm}$ ), type II (4 to $7 \mathrm{~mm}$ ) and type III ( 8 to 16 $\mathrm{mm}$ ) (Figure 2) [10].

3. Width of OF and CP: The horizontal width of the $\mathrm{CP}$ was measured bilaterally. The width of $\mathrm{OF}$ was measured bilaterally from the midpoint of the MERP point and the CP (Figure 1).

4. Lateral lamella-cribriform plate angle (LLCPA): The angle between LL and the horizontal plane continuing from $\mathrm{CP}$ was evaluated and divided into three types according to the Gera classification: type I $\left(>80^{\circ}\right)$, type II $\left(45^{\circ}\right.$ to $\left.80^{\circ}\right)$ and type III $\left(<45^{\circ}\right)$ (Figure 3) [11].

5. Nasal septum deviation (NSD) side and angle:

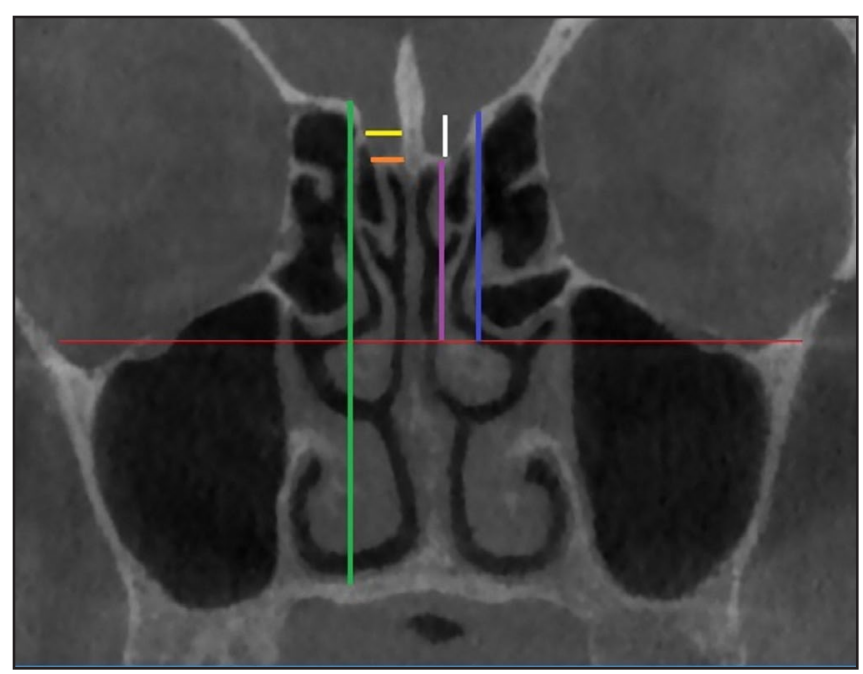

Figure 1. The measurements of olfactor fossa (OF) in coronal section. Green line $=$ nasal floor height; blue line $=$ medial etmoid roof point height; purple line $=$ cribriform plate $(\mathrm{CP})$ height; white line $=\mathrm{CP}$ depth; yellow line $=\mathrm{OF}$ width; orange line $=\mathrm{CP}$ width; red line $=$ the horizontal plane passing through the infraorbital foramen on both sides.

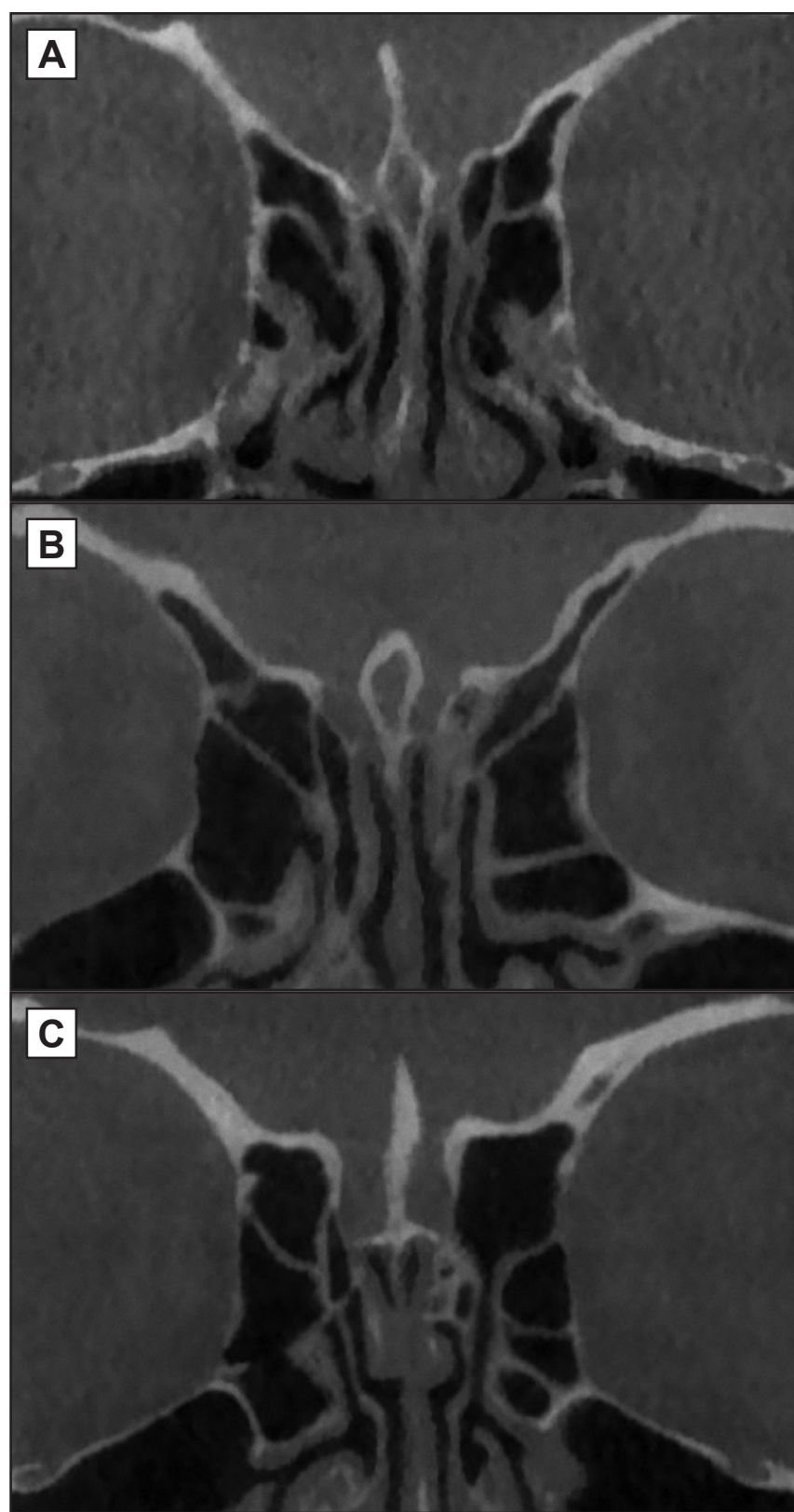

Figure 2. Keros classification: A = type I; B = type II; C = type III.

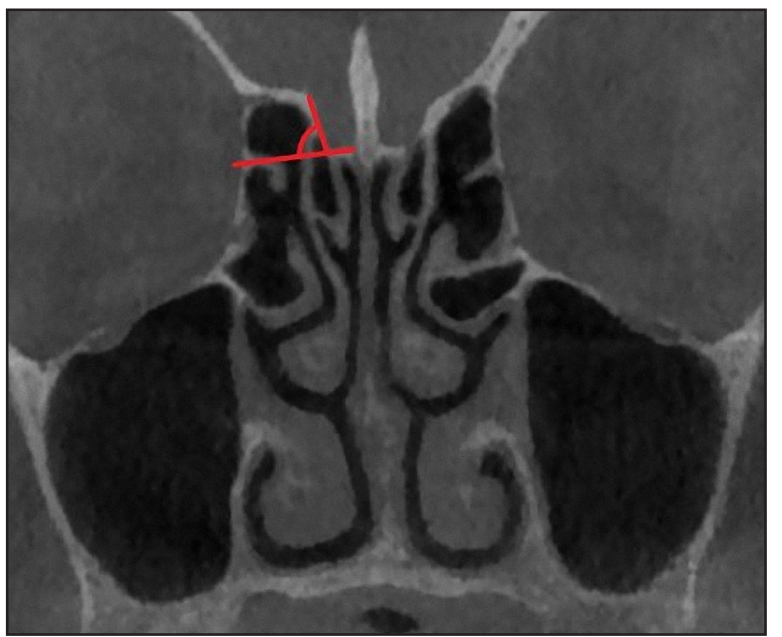

Figure 3. The measurement of the lateral lamella cribriform plate angle. (page number not for citation purposes) 
NSD side classified as right and left. The NSD angle (NSDA) was measured as the angle between the midpoint of the $\mathrm{CP}$ and the most prominent bone point of the deviated septum (Figure 4).

All measurements were made by one observer - oral and maxillofacial radiologist (C.Ö.K.). To determine intra-observer consistency, linear measurements were repeated 4 weeks later on images of 77 individuals (20\% of images) randomly selected by the same observer. The intra-observer reliability was evaluated using the intra-class correlation coefficient for all variables, and the intra-class correlation coefficients were between 0.87 and 0.92 .

\section{Statistical analysis}

The data obtained were assessed using descriptive statistical methods (mean, frequency, percentage). Kolmogorov-Smirnov test was used to evaluate the data distribution. The t-test and one-way ANOVA were used when testing the differences between the normally distributed group averages. Pearson's correlation test was used to evaluate the correlation between measurements. The Chi-square test was used to compare categorical variables. Parametric and nonparametric data were expressed as mean and standard deviation (M [SD]). Statistical analysis was performed using IBM SPSS Version 26 (IBM Inc.; Chicago, Illinois, USA). The significance level (P-value) was accepted as 0.05 .

\section{RESULTS}

In this study, the morphological evaluations of OF were made on images of 385 individuals aged 9 to 77 years (38 [17] years). The study group consisted of 290 female and 95 male.

Table 1 presents the mean of NF, MERP and CP heights, $\mathrm{CP}$ depth, $\mathrm{CP}$ and $\mathrm{OF}$ widths, LLCPA measured in coronal sections and shows their differences according to age groups, gender, side, Gera classification and Keros classification. While the mean of NF height and CP width were statistically significantly higher in males, the mean of $\mathrm{OF}$ width was found to be higher in females. It was observed that the mean heights of NF and MERP were statistically significantly higher at the age of 61 and over. Statistically, a significant difference was found between the right side and left side in mean NF, MERP and CP heights, CP depth and LLCPA $(\mathrm{P} \leq 0.05)$. NF, MERP, and $\mathrm{CP}$ heights, $\mathrm{CP}$ depth and LLCPA were statistically significant differences according to Keros classification $(\mathrm{P} \leq 0.05)$.

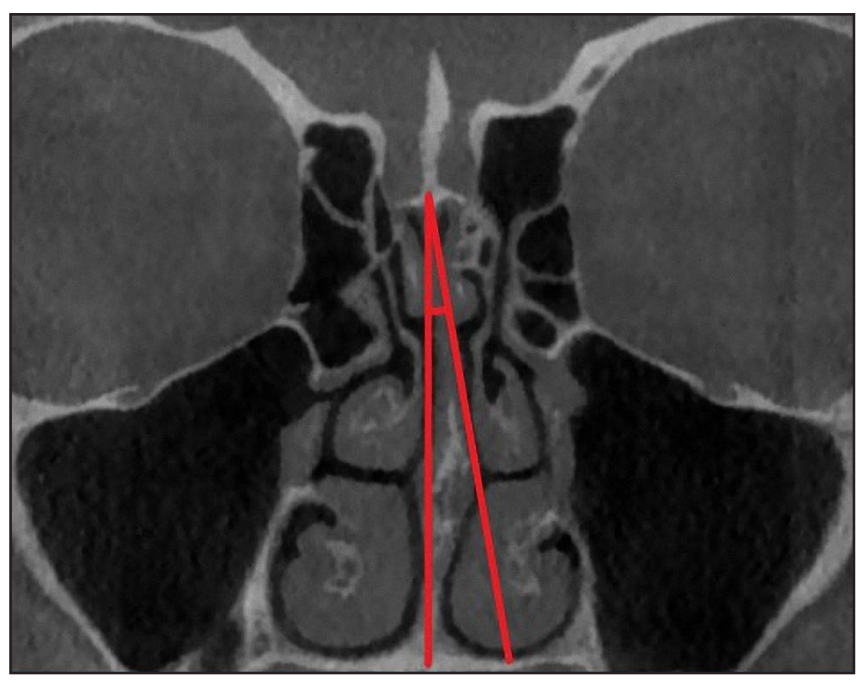

Figure 4. The measurement of the nasal septum deviation angle.

The mean of NF and MERP heights, CP depth, CP width, and LLCPA were statistically significant differences according to Gera classification $(\mathrm{P} \leq 0.05)$. There was a positive correlation between $\mathrm{CP}$ depth and LLCPA, NF, MERP, CP heights $(\mathrm{P} \leq 0.05)$. There was a negative correlation between the OF width and the CP depth, NF, MERP heights $(\mathrm{P} \leq 0.05)$ (Table 2).

According to Keros classification in total 770 olfactory fossae, type I was in 137 (17.8\%), type II in $554(71.9 \%)$ and type III in $79(10.3 \%)$. According to Gera classification, type I was in 267 (34.7\%), type II in $485(63 \%)$ and type III in $18(2.3 \%)$. There was no statistically significant difference in Gera and Keros classification according to gender, age groups and sides $(\mathrm{P}>0.05)$.

Table 3 shows the Gera and Keros classifications together for both sides. The most common combination was Keros type II and Gera type II (45.6\%), and the least was Keros type II and Gera type III $(1 \%)$. Keros type III and Gera type III were not seen together.

Table 4 presents the comparison of right and left sides according to the Keros classification. Accordingly, $271(70.3 \%)$ of 385 olfactory fossa were symmetrical. Asymmetry was also evaluated according to the difference between the right and left CP depths. The asymmetry of $\leq 1 \mathrm{~mm}$ was observed in 196 individuals $(50.9 \%), 1$ to $2 \mathrm{~mm}$ in 98 individuals $(255 \%),>2 \mathrm{~mm}$ in 68 individuals (17.7\%). In 23 OF only women, both sides were found to be equal millimetres. There was no statistically significant difference in asymmetry according to gender $(\mathrm{P}=0.58)$.

Table 5 shows the relationship of NF, MERP and CP heights, CP depth, CP and OF widths, LLCPA with the sides of the NSD. Only the right LLCPA showed a statistically significant difference according to the NSD sides $(\mathrm{P}=0.014)$. 
Table 1. The OF dimensions in coronal section according to the general, gender, age groups, Keros and Gera classifications

\begin{tabular}{|c|c|c|c|c|c|c|c|c|}
\hline & $\mathbf{N}$ & NF height & $\begin{array}{l}\text { MERP } \\
\text { height }\end{array}$ & CP height & CP depth & CP width & OF width & LLCPA \\
\hline & & Mean (SD) & Mean (SD) & Mean (SD) & Mean (SD) & Mean (SD) & Mean (SD) & Mean (SD) \\
\hline General & 770 & $50.44(3.2)$ & $26.35(2.8)$ & $20.66(2.53)$ & $5.67(1.62)$ & $2.72(0.5)$ & $3.51(0.7)$ & $74.16^{\circ}\left(12.02^{\circ}\right)$ \\
\hline \multicolumn{9}{|l|}{ Gender } \\
\hline Female & 290 & $49.94(2.93)$ & $26.39(2.76)$ & $20.68(2.52)$ & $5.69(1.61)$ & $2.67(0.5)$ & $3.43(0.71)$ & $74.55^{\circ}\left(11.92^{\circ}\right)$ \\
\hline Male & 95 & $51.97(3.52)$ & $26.21(2.91)$ & $20.59(2.61)$ & $5.62(1.64)$ & $2.84(0.47)$ & $3.77(0.62)$ & $72.97^{\circ}\left(12.32^{\circ}\right)$ \\
\hline P-value & & $0.000^{\mathrm{a}}$ & 0.6 & 0.759 & 0.717 & $0.004^{\mathrm{a}}$ & $0.000^{\mathrm{a}}$ & 0.269 \\
\hline \multicolumn{9}{|c|}{ Age groups } \\
\hline $9-18$ & 83 & $49.65(2.58)$ & $26.28(2.51)$ & $20.64(2.49)$ & $5.63(1.7)$ & $2.73(0.5)$ & $3.61(0.72)$ & $76.42^{\circ}\left(12.83^{\circ}\right)$ \\
\hline $19-30$ & 70 & $50.21(3.77)$ & $26.57(3.14)$ & $20.55(2.63)$ & $6.02(1.67)$ & $2.77(0.56)$ & $3.48(0.77)$ & $74.9^{\circ}\left(10.7^{\circ}\right)$ \\
\hline $31-45$ & 76 & $50.09(2.8)$ & $25.66(2.5)$ & $20.27(2.51)$ & $5.38(1.49)$ & $2.71(0.43)$ & $3.43(0.66)$ & $73.99^{\circ}\left(11.53^{\circ}\right)$ \\
\hline $46-60$ & 112 & $50.66(3.02)$ & $26.31(2.77)$ & $20.69(2.57)$ & $5.61(1.44)$ & $2.66(0.51)$ & $3.48(0.62)$ & $72.71^{\circ}\left(11.84^{\circ}\right)$ \\
\hline $61-77$ & 44 & $52.35(3.69)$ & $27.36(3.05)$ & $21.47(2.33)$ & $5.86(1.96)$ & $2.76(0.49)$ & $3.61(0.81)$ & $72.70^{\circ}\left(13.43^{\circ}\right)$ \\
\hline P-value & & $0.000^{\mathrm{b}}$ & $0.027^{\mathrm{b}}$ & 0.168 & 0.163 & 0.631 & 0.436 & 0.242 \\
\hline \multicolumn{9}{|l|}{ Side } \\
\hline Right & 385 & $50.21(3.34)$ & $26.1(2.96)$ & $20.5(2.54)$ & $5.59(1.79)$ & $2.73(0.58)$ & $3.49(0.75)$ & $72.23^{\circ}\left(13.76^{\circ}\right)$ \\
\hline Left & 385 & $50.67(3.33)$ & $26.59(2.89)$ & $20.82(2.58)$ & $5.76(1.81)$ & $2.7(0.63)$ & $3.54(0.86)$ & $76.09^{\circ}\left(14.41^{\circ}\right)$ \\
\hline P-value & & $0.000^{\mathrm{a}}$ & $0.000^{\mathrm{a}}$ & $0.000^{\mathrm{a}}$ & $0.038^{\mathrm{a}}$ & 0.405 & 0.242 & $0.000^{\mathrm{a}}$ \\
\hline \multicolumn{9}{|c|}{ Keros classification } \\
\hline Type I & 137 & $48.28(2.97)$ & $24.45(2.48)$ & $21.11(2.53)$ & $3.3(0.83)$ & $2.66(0.67)$ & $3.53(0.81)$ & $66.82^{\circ}\left(15.71^{\circ}\right)$ \\
\hline Type II & 554 & $50.61(3.18)$ & $26.4(2.75)$ & $20.6(2.59)$ & $5.79(1.15)$ & $2.72(0.6)$ & $3.53(0.82)$ & $75.1^{\circ}\left(13.29^{\circ}\right)$ \\
\hline Type III & 79 & $53.01(2.79)$ & $29.24(2.41)$ & $20.30(2.34)$ & $8.93(0.87)$ & $2.80(0.48)$ & $3.38(0.64)$ & $80.26^{\circ}\left(13.95^{\circ}\right)$ \\
\hline P-value & & $0.000^{\mathrm{b}}$ & $0.000^{\mathrm{b}}$ & $0.049^{\mathrm{b}}$ & $0.000^{\mathrm{b}}$ & 0.249 & 0.286 & $0.000^{\mathrm{b}}$ \\
\hline \multicolumn{9}{|c|}{ Gera classification } \\
\hline Type I & 267 & $50.92(3.2)$ & $26.78(2.82)$ & $20.46(2.56)$ & $6.29(1.82)$ & $2.77(0.53)$ & $3.41(0.79)$ & $88.82^{\circ}\left(9.15^{\circ}\right)$ \\
\hline Type II & 485 & $50.24(3.41)$ & $26.17(2.96)$ & $20.76(2.55)$ & $5.40(1.7)$ & $2.68(0.63)$ & $3.53(0.82)$ & $67.18^{\circ}\left(8.1^{\circ}\right)$ \\
\hline Type III & 18 & $48.93(2.51)$ & $24.72(2.76)$ & $20.85(2.94)$ & $3.86(1.13)$ & $2.95(0.64)$ & $3.77(0.58)$ & $44.80^{\circ}\left(16.91^{\circ}\right)$ \\
\hline P-value & & $0.004^{\mathrm{b}}$ & $0.001^{\mathrm{b}}$ & 0.293 & $0.000^{\mathrm{b}}$ & $0.032^{\mathrm{b}}$ & 0.281 & $0.000^{\mathrm{b}}$ \\
\hline
\end{tabular}

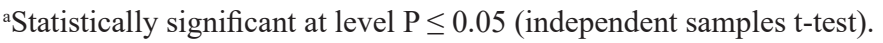

${ }^{\mathrm{b} S t a t i s t i c a l l y ~ s i g n i f i c a n t ~ a t ~ l e v e l ~} \mathrm{P} \leq 0.05$ (ANOVA test).

$\mathrm{N}=$ number of patients, $\mathrm{OF}=$ olfactor fossa; $\mathrm{SD}=$ standard deviation; $\mathrm{NF}=$ nasal floor; $\mathrm{MERP}=$ medial etmoid roof point; $\mathrm{CP}=\mathrm{cribriform}$ plate; LLCPA = lateral lamella cribriform plate angle.

Table 2. Correlation and significance values between measurements

\begin{tabular}{l|c|c|c|c|c|c|c}
\hline & NF height & MERP height & CP height & CP depth & CP width & OF width & LLCPA \\
\hline NF height & 1 & $\begin{array}{c}\mathrm{r}=0.61^{\mathrm{b}} \\
(\mathrm{P}=0.000)\end{array}$ & $\begin{array}{c}\mathrm{r}=0.43^{\mathrm{b}} \\
(\mathrm{P}=0.000)\end{array}$ & $\begin{array}{c}\mathrm{r}=0.39^{\mathrm{b}} \\
(\mathrm{P}=0.000)\end{array}$ & $\begin{array}{c}\mathrm{r}=-0.004 \\
(\mathrm{P}=0.934)\end{array}$ & $\begin{array}{c}\mathrm{r}=-0.1^{\mathrm{a}} \\
(\mathrm{P}=0.037)\end{array}$ & $\begin{array}{c}\mathrm{r}=0.17^{\mathrm{b}} \\
(\mathrm{P}=0.001)\end{array}$ \\
\hline MERP height & - & 1 & $\begin{array}{c}\mathrm{r}=0.82^{\mathrm{b}} \\
(\mathrm{P}=0.000)\end{array}$ & $\begin{array}{c}\mathrm{r}=0.44^{\mathrm{b}} \\
(\mathrm{P}=0.000)\end{array}$ & $\begin{array}{c}\mathrm{r}=-0.002 \\
(\mathrm{P}=0.975)\end{array}$ & $\begin{array}{c}\mathrm{r}=-0.14^{\mathrm{b}} \\
(\mathrm{P}=0.005)\end{array}$ & $\begin{array}{c}\mathrm{r}=0.21^{\mathrm{b}} \\
(\mathrm{P}=0.000)\end{array}$ \\
\hline CP height & - & - & 1 & $\begin{array}{c}\mathrm{r}=0.14^{\mathrm{a}} \\
(\mathrm{P}=0.004)\end{array}$ & $\begin{array}{c}\mathrm{r}=-0.006 \\
(\mathrm{P}=0.904)\end{array}$ & $\begin{array}{c}\mathrm{r}=-0.09 \\
(\mathrm{P}=0.065)\end{array}$ & $\begin{array}{c}\mathrm{r}=0.01 \\
(\mathrm{P}=0.851)\end{array}$ \\
\hline CP depth & - & - & - & 1 & $\begin{array}{c}\mathrm{r}=0.01 \\
(\mathrm{P}=0.847)\end{array}$ & $\begin{array}{c}\mathrm{r}=-0.101^{\mathrm{a}} \\
(\mathrm{P}=0.047)\end{array}$ & $\begin{array}{c}\mathrm{r}=0.34^{\mathrm{b}} \\
(\mathrm{P}=0.000)\end{array}$ \\
\hline CP width & - & - & - & - & 1 & $\begin{array}{c}\mathrm{r}=0.61^{\mathrm{b}} \\
(\mathrm{P}=0.000)\end{array}$ & $\begin{array}{c}\mathrm{r}=0.06 \\
(\mathrm{P}=0.222)\end{array}$ \\
\hline OF width & - & - & - & - & - & 1 & $\begin{array}{c}\mathrm{r}=-0.08 \\
(\mathrm{P}=0.106)\end{array}$ \\
\hline LLCPA & - & - & - & - & - & - & 1 \\
\hline
\end{tabular}

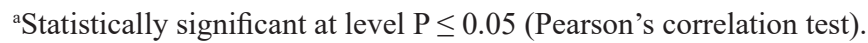

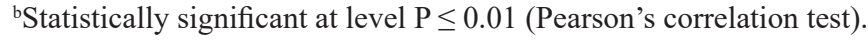

$\mathrm{NF}=$ nasal floor; $\mathrm{MERP}=$ medial etmoid roof point; $\mathrm{CP}=$ cribriform plate LLCPA $=$ lateral lamella cribriform plate angle. 
Table 3. Co-distribution of the Gera and Keros classifications

\begin{tabular}{l|c|c|c|c}
\hline \multirow{2}{*}{$\begin{array}{c}\text { Gera } \\
\text { classification }\end{array}$} & \multicolumn{4}{|c}{ Keros classification } \\
\cline { 2 - 5 } & Type I & Type II & Type III & Total \\
\cline { 2 - 5 } & $\mathbf{N ~ ( \% )}$ & $\mathbf{N}(\%)$ & $\mathbf{N ~ ( \% )}$ & $\mathbf{N}(\%)$ \\
\hline Type I & $26(3.4)$ & $195(25.3)$ & $46(6)$ & $267(34.7)$ \\
\hline Type II & $101(13.1)$ & $351(45.6)$ & $33(4.3)$ & $485(63)$ \\
\hline Type III & $10(1.3)$ & $8(1)$ & $0(0)$ & $18(2.3)$ \\
\hline Total & $137(17.8)$ & $554(71.9)$ & $79(10.3)$ & $770(100)$ \\
\hline
\end{tabular}

$\mathrm{N}=$ number of sides.

Table 4. Distribution of Keros classification according to sides

\begin{tabular}{|c|c|c|c|c|}
\hline \multirow{3}{*}{$\begin{array}{c}\text { Keros } \\
\text { classification- } \\
\text { left }\end{array}$} & \multicolumn{4}{|c|}{ Keros classification-right } \\
\hline & Type I & Type II & Type III & Total \\
\hline & N (\%) & $\mathbf{N}(\%)$ & $\mathbf{N}(\%)$ & $\mathbf{N}(\%)$ \\
\hline Type I & $32(8.3)$ & $25(6.4)$ & $1(0.3)$ & $58(15)$ \\
\hline Type II & $46(11.9)$ & $221(57.4)$ & $20(5.1)$ & $287(74.5)$ \\
\hline Type III & $1(0.3)$ & $21(5.4)$ & $18(4.6)$ & $40(10.5)$ \\
\hline Total & $79(20.5)$ & $267(69.3)$ & $39(10.1)$ & $385(100)$ \\
\hline
\end{tabular}

$\mathrm{N}=$ number of patients.

Right NSD was found in 218 and left NSD in 167 of 385 individuals. There was no statistically significant difference in NSD sides according to gender $(\mathrm{P}=$ $0.139)$. The NSDA of females was $5.7^{\circ}\left(2.6^{\circ}\right)$ and $6.1^{\circ}$ $\left(2.7^{\circ}\right)$ for males. There was no statistically significant difference in NSDA according to age groups and gender $(\mathrm{P}=0.759, \mathrm{P}=0.145)$.

\section{DISCUSSION}

The CT evaluation of the nose and paranasal sinus is important in the evaluation of patients before ESS. OF asymmetries, anatomical variations of LLCP and $\mathrm{CP}$ are critical in ESS, as they can have dangerous consequences. CT has made a great contribution to the evaluation of many diseases such as nasal and sinus diseases and important anatomical regions [3] Demeslay et al. [12] confirmed the benefit of CBCT for paranasal imaging. They reported that $\mathrm{CBCT}$ gave equivalent results in the assessment of $\mathrm{CP}$ and $\mathrm{OF}$ with lower doses relative to CT. However, few studies

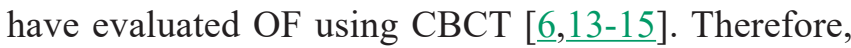
in this study, we showed that the region of OF can be evaluated with CBCT and to provide a detailed examination of the relevant region.

The mean CP depth in the studies by Karatay et al. [16], Babu et al. [17], and Salroo et al. [18] was 4.89, 5.26 and $5.08 \mathrm{~mm}$, respectively. They observed a significant difference in $\mathrm{CP}$ depth between men and
Table 5. Comparison of measurement results on the sides according to the NSD side

\begin{tabular}{l|l|c|c|c|c|c}
\hline \multicolumn{2}{c|}{} & \multicolumn{2}{|c|}{ NSD right } & \multicolumn{2}{c|}{ NSD left } & \multirow{2}{*}{ P-value } \\
\cline { 3 - 6 } & & Mean & SD & Mean & SD & \\
\hline \multirow{2}{*}{ NF height } & Right & 50.16 & 3.38 & 50.28 & 3.3 & 0.708 \\
\cline { 2 - 6 } & Left & 50.51 & 3.52 & 50.89 & 3.05 & 0.261 \\
\hline \multirow{2}{*}{ MERP height } & Right & 25.96 & 2.99 & 26.28 & 2.92 & 0.302 \\
\cline { 2 - 6 } & Left & 26.41 & 2.92 & 26.83 & 2.84 & 0.163 \\
\hline \multirow{3}{*}{ CP height } & Right & 20.47 & 2.47 & 20.53 & 2.63 & 0.822 \\
\cline { 2 - 6 } & Left & 20.72 & 2.57 & 20.95 & 2.59 & 0.388 \\
\hline \multirow{3}{*}{ CP depth } & Right & 5.47 & 1.83 & 5.74 & 1.74 & 0.148 \\
\cline { 2 - 6 } & Left & 5.68 & 1.75 & 5.85 & 1.89 & 0.371 \\
\hline \multirow{2}{*}{ OF width } & Right & 2.72 & 0.63 & 2.75 & 0.52 & 0.558 \\
\cline { 2 - 6 } & Left & 2.69 & 0.6 & 2.72 & 0.66 & 0.647 \\
\hline \multirow{2}{*}{ LLCPA } & Right & 3.47 & 0.77 & 3.52 & 0.71 & 0.518 \\
\cline { 2 - 6 } & Left & 3.52 & 0.84 & 3.57 & 0.88 & 0.562 \\
\hline & Right & 70.2 & 13.43 & 74.2 & 13.98 & $0.014^{\mathrm{a}}$ \\
\hline & Left & 76.06 & 14.61 & 76.13 & 14.2 & 0.965 \\
\hline
\end{tabular}

a Statistically significant at level $\mathrm{P} \leq 0.05$ (Paired samples t-test). $\mathrm{NF}=$ nasal floor; $\mathrm{MERP}=$ medial etmoid roof point; $\mathrm{CP}=$ cribriform plate; $\mathrm{OF}=$ olfactor fossa; LLCPA = lateral lamella cribriform plate angle; NSD = nasal septum deviation.

women [16-18]. While Skorek et al. [19] reported that there was no statistically significant difference in CP depth according to gender, age and side, they reported a significant difference in $\mathrm{OF}$ and $\mathrm{CP}$ widths according to gender. In our study, the mean $\mathrm{CP}$ depth was $5.67 \mathrm{~mm}$ and there was no statistically significant difference according to gender and age groups. The mean widths of $\mathrm{OF}$ and $\mathrm{CP}$ were statistically significant in our study. Unlike other studies, in our study, the mean CP depth was statistically significant according to the side $[\underline{1}, \underline{13}, \underline{16}]$. The mean CP depth on the left was greater than the right. Also, NF, MERP and CP heights, and LLCPA were statistically significant according to the side.

Unlike previous studies, the relationship between the Keros and Gera classifications and the measurements performed was investigated in our study. NF, MERP and CP heights and LLCPA showed statistically significant differences according to Keros classification. While the highest NF, MERP heights and LLCPA were observed in type III, the highest CP height was observed in type II. NF and MERP heights, CP depth, CP width and LLCPA showed statistically significant differences according to Gera classification. Gera et al. [11] reported a positive correlation between CP depth and LLCPA. Abdullah et al. [7] reported a positive correlation between CP depth and LLCPA, MERP and CP heights. In our study, while there was a significant positive correlation between $\mathrm{CP}$ depth 
and NF, MERP and CP heights and LLCPA, there was a significant negative correlation between $\mathrm{CP}$ depth and OF width. It is noteworthy that there is a positive correlation between CP depth and LLCPA. According to the Keros classification, increasing the depth of $\mathrm{CP}$ means increasing the risk, while increasing the LLCPA in the Gera classification means decreasing the risk. If it is interpreted in line with the data we have obtained, the increase in the depth of $\mathrm{CP}$, while the increase in the LLCPA ensures that the current risk remains moderate.

In our study, the most common were Keros type II (71.9\%), followed by Keros type I (17.8\%), Keros type III $(10.3 \%)$. While a few studies reported the most common Keros type I $[\underline{1}, \underline{2}, \underline{7}, \underline{20}, 21]$, most studies were the most common type II $[\underline{3}-5, \underline{8}, \underline{13-15}, \underline{17-19}, \underline{22-}$ 28], consistent with our study. The distributions according to the Keros classification in the studies conducted in the Turkish population are presented in Table 6.

Skorek et al. [19], Abdullah et al. [7] reported the rate of asymmetry according to the Keros classification as $20 \%$ and $26 \%$, respectively. We determined the rate of OF showing asymmetry according to the Keros classification as $29.7 \%$ (Figure 5). Some researchers evaluated the asymmetry in OF with the difference between right and left CP heights. They classified this difference as $\leq 1 \mathrm{~mm}, 1$ to $2 \mathrm{~mm},>2 \mathrm{~mm}$. Kaplanoglu et al. [4], Erdogan et al. [23] , Babu et al. [17] reported that the rate of OF with a difference of $\leq 1 \mathrm{~mm}$ was $89 \%, 50.9 \%$, and $64.5 \%$, respectively. In our study, among 362 individuals with asymmetry, 196 (54.1\%) had a difference of $\leq 1 \mathrm{~mm}, 98(27.1 \%)$ a difference of 1 to $2 \mathrm{~mm}$, and $68(18.8 \%)$ a difference of $>2 \mathrm{~mm}$ between the two sides.

Gera et al. [11] reported that the mean LLCPA was $71.7^{\circ}$ and they detected the most common type II (62.7\%). Abdullah et al. [7] reported that detected the mean LLCPA of $70.1^{\circ}$ and the most common type II (72.3\%). In our study, the mean LLCPA was found
Table 6. Keros classification in studies conducted in Turkish population

\begin{tabular}{l|c|c|c|c|c}
\hline \multicolumn{1}{c|}{ Study } & $\begin{array}{c}\text { Imagine } \\
\text { technique }\end{array}$ & $\begin{array}{c}\text { Number of } \\
\text { patients }\end{array}$ & $\begin{array}{c}\text { Type I } \\
\mathbf{( \% )}\end{array}$ & $\begin{array}{c}\text { Type II } \\
\mathbf{( \% )}\end{array}$ & $\begin{array}{c}\text { Type III } \\
\mathbf{( \% )}\end{array}$ \\
\hline $\begin{array}{l}\text { Kaplanoglu et } \\
\text { al. [4] }\end{array}$ & CT & 500 & 13.4 & 76.1 & 10.5 \\
\hline Bayrak et. al. [6] & CBCT & 225 & 13.8 & 75.1 & 11.1 \\
\hline Erdem et al. [8] & CT & 136 & 8.1 & 59.6 & 32.3 \\
\hline $\begin{array}{l}\text { Karatay et al. } \\
\text { [16] }\end{array}$ & CT & 522 & 30.8 & 66.7 & 2.4 \\
\hline Asal et al. [22] & $\mathrm{CT}$ & 300 & 16 & 67.7 & 16.3 \\
\hline $\begin{array}{l}\text { Erdogan et al. } \\
\text { [23] }\end{array}$ & $\mathrm{CT}$ & 110 & 10 & 67.7 & 22.3 \\
\hline $\begin{array}{l}\text { Yenigun et al. } \\
\text { [25] }\end{array}$ & $\mathrm{CT}$ & 184 & 26 & 56 & 18.9 \\
\hline $\begin{array}{l}\text { Güler et al. [26] } \\
\text { Sari et al. [27] }\end{array}$ & $\mathrm{CT}$ & 300 & 26 & 66 & 8 \\
\hline Yazici et al. [28] & $\mathrm{CT}$ & 150 & 9.3 & 54 & 36.7 \\
\hline Present Study & $\mathrm{CBCT}$ & 385 & 17.8 & 71.9 & 10.3 \\
\hline
\end{tabular}

$\mathrm{CT}=$ computed tomography; $\mathrm{CBCT}=$ cone-beam computed tomography.

to be $74.1^{\circ}$, which is a higher value than in previous studies. According to the Gera classification, the most common were type II $(62.9 \%)$, consistent with previous studies. The reason for the higher LLCPA may be the population differences in the studies.

\section{CONCLUSIONS}

Keros and Gera classifications help the safe approach to evaluate the olfactory fossa before endoscopic sinus surgery. The main focus of the presented study was to evaluate the olfactory fossa using cone-beam computed tomography and to provide safe dimensions with measurement results for the endoscopic sinus surgery. The study showed that there is a positive correlation between lateral lamella-cribriform

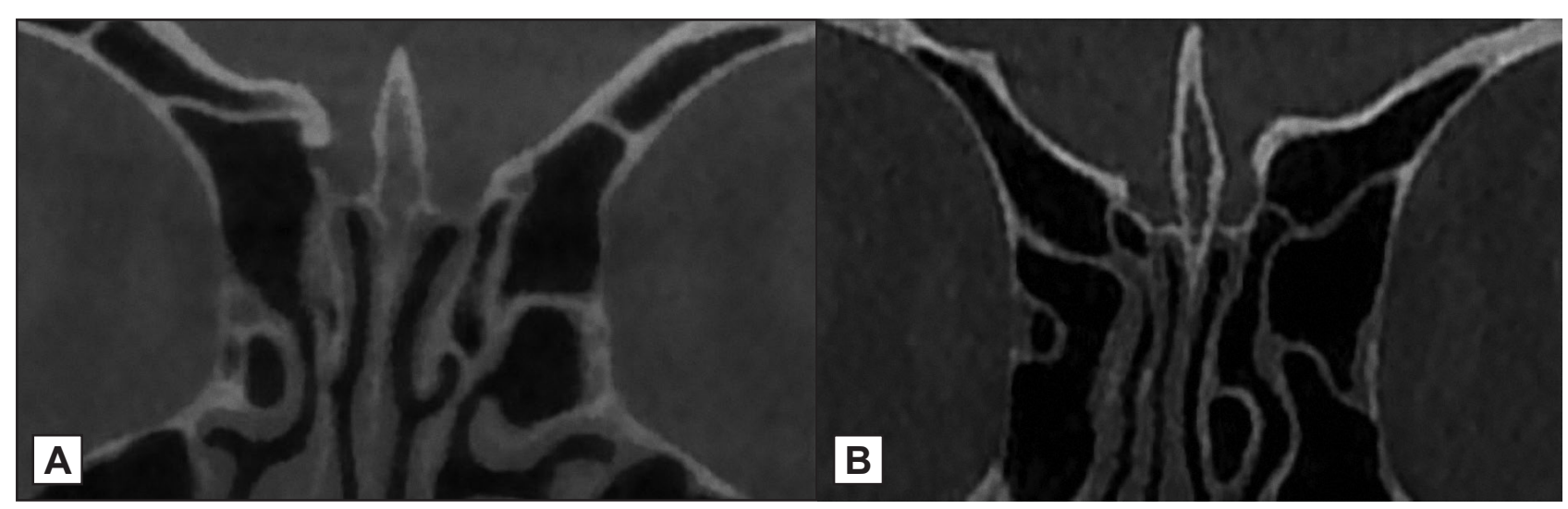

Figure 5. Asymmetric olfactory fossa examples: A = type III on the left, type I on the right; B = type II on the left, type III on the right. 
plate angle and cribriform plate depth. And this suggests that it may moderate the risk. In addition, cone-beam computed tomography is useful in preoperative examination of patients with diseases in the sinonasal region and adjacent structures.

\section{ACKNOWLEDGMENT AND DISCLOSURE STATEMENTS}

The authors declare that they have no conflict of interest. This research did not receive any specific grant from funding agencies in the public, commercial, or not-for-profit sectors.

\section{REFERENCES}

1. Shama S, Montaser M. Variations of the height of the ethmoid roof among Egyptian adult population: MDCT study. Egypt J Radiol Nucl Med. 2015 Dec;46(4):929-36. [doi: 10.1016/j.ejrnm.2015.07.013]

2. Shrestha B, Karmacharya S, Shrestha K. Radiological Analysis of Olfactory Fossa Depth: A Tertiary Care Hospital Based Study. BJHS. 2019 Jan;3(3):576-80. [doi: 10.3126/bjhs.v3i3.22193]

3. V AM, Santosh B. A Study of Clinical Significance of the Depth of Olfactory Fossa in Patients Undergoing Endoscopic Sinus Surgery. Indian J Otolaryngol Head Neck Surg. 2017 Dec;69(4):514-522. [Medline: 29238684] [PMC free article: 5714917] [doi: 10.1007/s12070-017-1229-8]

4. Kaplanoglu H, Kaplanoglu V, Dilli A, Toprak U, Hekimoğlu B. An analysis of the anatomic variations of the paranasal sinuses and ethmoid roof using computed tomography. Eurasian J Med. 2013 Jun;45(2):115-25. [Medline: 25610263] [PMC free article: 4261488] [doi: 10.5152/eajm.2013.23]

5. Adeel M, Ikram M, Rajput MS, Arain A, Khattak YJ. Asymmetry of lateral lamella of the cribriform plate: a softwarebased analysis of coronal computed tomography and its clinical relevance in endoscopic sinus surgery. Surg Radiol Anat. 2013 Nov;35(9):843-7. [Medline: 23525641] [doi: 10.1007/s00276-013-1106-4]

6. Bayrak S, Aktuna Belgin C, Orhan K. Evaluation of the Relationship Between Olfactory Fossa Measurements and Nasal Septum Deviation for Endoscopic Sinus Surgery. J Craniofac Surg. 2020 May/Jun;31(3):801-803. [Medline: 31934966] [doi: $10.1097 /$ SCS.0000000000006168]

7. Abdullah B, Chew SC, Aziz ME, Shukri NM, Husain S, Joshua SW, Wang Y, Snidvongs K. A new radiological classification for the risk assessment of anterior skull base injury in endoscopic sinus surgery. Sci Rep. 2020 Mar 12;10(1):4600. [Medline: 32165705] [PMC free article: 7067776] [doi: 10.1038/s41598-020-61610-1]

8. Erdem G, Erdem T, Miman MC, Ozturan O. A radiological anatomic study of the cribriform plate compared with constant structures. Rhinology. 2004 Dec;42(4):225-9. [Medline: 15626256]

9. Kyriakou Y, Kolditz D, Langner O, Krause J, Kalender W. Digitale Volumentomografie (DVT) und Mehrschicht-SpiralCT (MSCT): eine objektive Untersuchung von Dosis und Bildqualität [Digital volume tomography (DVT) and multislice spiral CT (MSCT): an objective examination of dose and image quality]. Rofo. 2011 Feb;183(2):144-53. German. [Medline: 20922645] [doi: 10.1055/s-0029-1245709]

10. Keros P. [On the practical value of differences in the level of the lamina cribrosa of the ethmoid]. Z Laryngol Rhinol Otol. 1962 Nov;41:809-13. German. [Medline: 14032071]

11. Gera R, Mozzanica F, Karligkiotis A, Preti A, Bandi F, Gallo S, Schindler A, Bulgheroni C, Ottaviani F, Castelnuovo P. Lateral lamella of the cribriform plate, a keystone landmark: proposal for a novel classification system. Rhinology. 2018 Mar 1;56(1):65-72. [Medline: 29069120] [doi: 10.4193/Rhin17.067]

12. Demeslay J, Vergez S, Serrano E, Chaynes P, Cantet P, Chaput B, de Bonnecaze G. Morphological concordance between CBCT and MDCT: a paranasal sinus-imaging anatomical study. Surg Radiol Anat. 2016 Jan;38(1):71-8. [Medline: 26239897] [doi: 10.1007/s00276-015-1509-5]

13. Costa ALF, Paixão AK, Gonçalves BC, Ogawa CM, Martinelli T, Maeda FA, Trivino T, Lopes SLPC. Cone Beam Computed Tomography-Based Anatomical Assessment of the Olfactory Fossa. Int J Dent. 2019 Apr 1;2019:4134260. [Medline: 31073308] [PMC free article: 6470455] [doi: 10.1155/2019/4134260]

14. Güldner C, Diogo I, Windfuhr J, Bien S, Teymoortash A, Werner JA, Bremke M. Analysis of the fossa olfactoria using cone beam tomography (CBT). Acta Otolaryngol. 2011 Jan;131(1):72-8. [Medline: 20863153] [doi: $10.3109 / 00016489.2010 .506653$ ]

15. Savvateeva DM, Güldner C, Murthum T, Bien S, Teymoortash A, Werner JA, Bremke M. Digital volume tomography (DVT) measurements of the olfactory cleft and olfactory fossa. Acta Otolaryngol. 2010 Mar;130(3):398-404. [Medline: 19883175] [doi: 10.3109/00016480903283741]

16. Karatay E, Avc1 H. Evaluation of olfactory fossa anatomy by computed tomography and the place of Keros classification in functional endoscopic sinus surgery. South Clin Ist Euras. 2021 Dec;32(1):47-52. [doi: 10.14744/scie.2020.88156]

17. Babu AC, Nair MRPB, Kuriakose AM. Olfactory fossa depth: CT analysis of 1200 patients. Indian J Radiol Imaging. 2018 Oct-Dec;28(4):395-400. [Medline: 30662198] [PMC free article: 6319094] [doi: 10.4103/ijri.IJRI_119_18]

18. Salroo I, Dar NH, Yousuf A, Lone KS. Computerised tomographic profile of ethmoid roof on basis of keros classification among ethnic Kashmiri's. Int J Otorhinolaryngol Head Neck Surg. 2016 Jan;2(1):1-5. [doi: 10.18203/issn.2454-5929.ijohns20151134] 
19. Skorek A, Tretiakow D, Szmuda T, Przewozny T. Is the Keros classification alone enough to identify patients with the 'dangerous ethmoid'? An anatomical study. Acta Otolaryngol. 2017 Feb;137(2):196-201. [Medline: 27608833] [doi: 10.1080/00016489.2016.1225316]

20. Alazzawi S, Omar R, Rahmat K, Alli K. Radiological analysis of the ethmoid roof in the Malaysian population. Auris Nasus Larynx. 2012 Aug;39(4):393-6. [Medline: 22055509] [doi: 10.1016/j.anl.2011.10.002]

21. Paber JELB, Cabato MSD, Villarta RL, Hernandez JG. Radiographic Analysis of the Ethmoid Roof based on KEROS Classification among Filipinos. Philipp J Otolaryngol Head Neck Surg. 2008 Jun;23(1):15-9. [doi: 10.32412/pjohns.v23i1.763]

22. Asal N, Bayar Muluk N, Inal M, Şahan MH, Doğan A, Arikan OK. Olfactory Fossa and New Angle Measurements: Lateral Lamella-Cribriform Plate Angle. J Craniofac Surg. 2019 Sep;30(6):1911-1914. [Medline: 31343591] [doi: 10.1097/SCS.0000000000005848]

23. Erdogan S, Keskin IG, Topdag M, Ozturk M, Sari F, Mutlu F. Ethmoid roof radiology; analysis of lateral lamella of cribriform plate. Otolaryngol Pol. 2015;69(6):53-7. [Medline: 26860608] [doi: 10.5604/00306657.1184543]

24. Muñoz-Leija MA, Yamamoto-Ramos M, Barrera-Flores FJ, Treviño-González JL, Quiroga-Garza A, Méndez-Sáenz MA, Campos-Coy MA, Elizondo-Rojas G, Guzmán-López S, Elizondo-Omaña RE. Anatomical variations of the ethmoidal roof: differences between men and women. Eur Arch Otorhinolaryngol. 2018 Jul;275(7):1831-1836. [Medline: 29744636] [doi: 10.1007/s00405-018-4992-6]

25. Yenigun A, Goktas SS, Dogan R, Eren SB, Ozturan O. A study of the anterior ethmoidal artery and a new classification of the ethmoid roof (Yenigun classification). Eur Arch Otorhinolaryngol. 2016 Nov;273(11):3759-3764. [Medline: 27115909] [doi: 10.1007/s00405-016-4064-8]

26. Güler C, Uysal IÖ, Polat K, Salk I, Müderris T, Koşar MI. Analysis of ethmoid roof and skull base with coronal section paranasal sinus computed tomography. J Craniofac Surg. 2012 Sep;23(5):1460-4. [Medline: 22976636] [doi: 10.1097/SCS.0b013e31825755b2]

27. Sari H, Yıldırım G, Önol SD, Özdemir E, Arslanoglu A, Gurpinar B, Kumral TL, Uyar Y, Salturk Z. Importance of Keros Classification in Surgery. Otolaryngol Open J. 2017 Dec;3(3):54-8. [doi: 10.17140/OTLOJ-3-143]

28. Yazici D. The Analysis of Computed Tomography of Paranasal Sinuses in Nasal Septal Deviation. J Craniofac Surg. 2019 Mar/Apr;30(2):e143-e147. [Medline: 30550450] [doi: 10.1097/SCS.0000000000005077]

\section{To cite this article:}

Özeren Keşkek C, Aytuğar E.

Radiological Evaluation of Olfactory Fossa with Cone-Beam Computed Tomography

J Oral Maxillofac Res 2021;12(3):e3

URL: http://www.ejomr.org/JOMR/archives/2021/3/e3/v12n3e3.pdf

doi: $\underline{10.5037 / \text { jomr.2021.12303 }}$

Copyright (C) Özeren Keşkek C, Aytuğar E. Published in the JOURNAL OF ORAL \& MAXILLOFACIAL RESEARCH (http://www.ejomr.org), 30 September 2021.

This is an open-access article, first published in the JOURNAL OF ORAL \& MAXILLOFACIAL RESEARCH, distributed under the terms of the Creative Commons Attribution-Noncommercial-No Derivative Works 3.0 Unported License, which permits unrestricted non-commercial use, distribution, and reproduction in any medium, provided the original work and is properly cited. The copyright, license information and link to the original publication on (http://www.ejomr.org) must be included. 